\title{
The Rise and Fall of the Islamic Empire and the Threat to the West
}

\author{
Anthony J. Dennis
}

Lima, OH: Wyndham Hall Press, 2001, 2d ed. 157 pages.

Historians and literary critics looking for examples of modern literature using classic Orientalist discourse will find The Rise and Fall of the Islamic Empire and the Threat to the West a useful tool. Anthony J. Dennis presents 1,400 years of history, interprets the Qur'an and the Shari ah, scrutinizes Sunni and Shi a sectarianism, psychoanalyzes Muslims, comments on the status of women, discusses international political and national movements, and gives diplomatic and military contingency plans for civilians and policymakers to stem the "Islamic threat" to the West in 157 pages (including notes). His second edition forward begins with a polite "I-told-you-so" claiming that 9/11 occurred because Americans were not as vigilant as he told them to be in his first edition (1996), that it was the "first chapter in what promises to be a long battle" (forward) between Islam and the West.

According to the author, the fall of communism ended the cold war system of checks and balances and allowed rogue Islamic states to flourish. Iran, being one of the oldest rogue states and an established enemy of the United States, took the USSR's place in stimulating and directing revolutions. Given that Muslims are religiously directed to hate all nonMuslims and western prosperity is a reminder of their shortcomings, Muslims are jealous and eager to embrace the new revolution.

Dennis outlines his argument in seven thin and successively shrinking chapters. He first laments the end of communism and the KGB, because nuclear arms, now unprotected, are being sold by Russian scientists and soldiers. Chapter 2 gives a cursory explanation of Islam and its ills, and chapter 3 describes how Iran, the great global Muslim thought-control center, overcame religious sectarian divides to stimulate revolutions in Central Asia and the Middle East. In chapter 4, Dennis again revisits the sale of nuclear arms to Islamic states, and in chapters 5 and 6 loosely describes how terrorism might occur with nuclear and conventional arsenals. He gives a generalized plan to minimize the diabolical Iranian-led Muslim threat in his last chapter, which includes using ballistic missiles (which, he explains, was delegitimized when the liberals dubbed it "Star Wars") and aiding the Russians in fighting independence movements among Muslims. 
For those policymakers and citizens concerned that these tactics may reach genocidal proportions, Dennis urges action from the "moral high ground" and not to target only Muslims, but anyone who challenges American ideology. Ordinary citizens must remain vigilant and watch for any suspicious people or acts near water purification centers, nuclear power plants, and public transportation centers, and the youth should be educated to recognize terrorists.

Dennis' book is wrought with problems. He stereotypes Muslims, calls for racial profiling, and furthers the fallacious notion of race. In an exercise of classic Orientalism, the author uses dichotomies: Islam versus the West, and the Qur'an versus democracy and the American Constitution. Islam is unfair, rigid, primitive, barbaric, and devalues the individual; democracy is just, flexible, modern, civil, and individualistic. The Constitution guarantees rights; the Qur'an denies them. The "Muslim man on the street" (Dennis does not discuss the average Muslim woman, because she is too oppressed) is simple and cannot understand democracy, yet is diabolical enough to use it to further Islamic tyranny. He hails Mustafa Kemal's modernization of Turkey despite that nation's oppression of its Muslims, and lauds Stalin's brutality because he neutralized national movements among the USSR's Muslims. Dennis ignores centuries of history to portray America as the champion of human rights, and even incorrectly declares its unanimous support for the International Declaration of Human Rights, a document that was drafted during the American segregationist period and subsequently met with much political and social resistance.

Dennis also uses the well-known Islamophobes Daniel Pipes and Samuel Huntington (the former is listed in his acknowledgements) to explain geopolitics. He clings to non-Muslim sources to explain the tenets of Islam, only citing Muslims in anti-western quotes (which are at the beginning of every chapter). He gives a homogenized picture of Islam through the use of blatant fabrications. By removing Qur'anic verses from their context and simplifying such complex concepts as kafir (unbeliever), Dennis states that all Muslims are religiously mandated to declare war against non-Muslims. He falsely claims that only an elite group of men can read the Qur'an and the Shari'ah, that the Shi a clerics in Iran control all Muslims, and that any challenge to political authority is blasphemy because Islam does not separate "church" and state. Dennis dismisses economic, political, social, and linguistic differences between predominately Muslim nations to claim that Muslims are united in hate and are fluent in Arabic. As a result, there are no impediments to world domination. 
His fallacious claims are off-set by inadequate research. He misleadingly sprinkles factoids from a single article to give the loose semblance of a well-researched paper. For example, to demonstrate the Iranian threat to the West, 35 of the 73 reference notes in a small 13-page chapter are from the same article. At least two other articles are used, on average, four times in the same 13-page chapter. Dennis abandons this strategy in his last five chapters, where his reference notes dwindle to a third of what they were. It it is unclear if Dennis believes that he has successfully deceived his reader, or if he could not maintain such poor academic standards.

Dennis' work falls short of full-blown hate literature because of his odd attempt at political correctness. He declares that blaming Islam for the radicalization of Muslims is faulty logic and equivalent to blaming the Bible for the Crusades, and that many Muslims in the West choose to live peaceful lives. He even buries a positive statement about religious tolerance during the golden era of Islam in his Orientalist discourse. But these types of statements contradict his central argument: The fundamental tenet of Islam is to declare war against all non-Muslims. These statements, plus "the moral high ground," appear to be placed to ease the conscience of citizens and policymakers, and perhaps even his own, so that they can use the Constitution to shield their freedoms while simultaneously using its rhetoric to smother the rights of others.

Nergis Mazid

Communications Instructor, Communications Department Georgian College, Barrie, Ontario, Canada 